\title{
The Mysterious Domination of Food Contaminants and Adulterants in Bangladesh
}

\author{
Mohiuddin AK* \\ Department of Pharmacy, World University of Bangladesh, Dhaka, Bangladesh \\ "Corresponding Author: Mohiuddin AK, Department of Pharmacy, World University of Bangladesh, 151/8, \\ Green Road Dhanmondi, Dhaka-1205, Bangladesh, E-mail: trymohi@gmail.com
}

Received: 29 November 2018; Accepted: 14 December 2018; Published: 24 January 2019

\begin{abstract}
Food adulteration and contamination are as old as the civilization itself. It is the consequence of the development of civilization, over utilization of nature, industrialization and in a price for the progression. It is highly prominent in Urban areas of Bangladesh. It is the consequence of commercialism of business people who are doing this knowingly to maximize profit. Higher degree of awareness shown by the people with higher educational background. Government regulatory agencies are less confident regarding food standard testing, as reported in the study. Educated people show higher degree of awareness of how the quality of food should be maintained. Regulatory authority is found to be in confidant in testing the food standard which also reflects their negligence. Safe food means, in general, there will be no danger from harmful elements that are deliberately added to food products in the country. The economic development of this country rarely reveals the basic literacy and consciousness of mass people. Necessary steps are to be taken to protect the environment for our own existence.
\end{abstract}

Purpose of the study: Brief review of chemical induced food contamination, their consequences and control. Healthcare providers/Policy makers have a major role play to concerned field.

Materials and Methods: Comprehensive literature search followed by consulting healthcare professionals about adulteration and food contamination. Hospital, clinic, newspaper journalists, NGO workers were interviewed and asked help for necessary books, journal, newsletters. A few western magazine and newspapers also observed to get 
necessary concern. Projections were based on various types of adulteration in food served/sold to general people from variety of sources.

Findings: Both general people and the old system, are responsible for this unlivable condition of Bangladesh. Population is not the sole for this instance. A sense of poor rules and regulation is always found everywhere. Negligence is becoming a widespread disease affecting illiterate to well educated, all kind of people.

Research limitations: Many articles and documents found in concerned area of research, but the scope of this research is on its focus point chemical induced food adulteration in Bangladesh. Still the most important aspect is covered, but fact is less amount of recent data obtained in few areas.

Practical Implication: The language of this article is too simple to understand by people with simple scientific literacy. Pharmacists, doctors, nurses, hospital authorities, public representatives, policy makers and regulatory authorities along with general people have to receive much from this article. Social Implication: Any article or research is based on the think doing good for mankind, at least going ahead from the present situation, overcoming problems and measures. Bangladesh has recently passed from the list of LDC country with massive economic development. The article should create a guideline for the future policy makers of both government and other sectors to review the alarming situation of chemical induced food contaminants in Bangladesh.

Social Implication: Any article or research is based on the think doing good for mankind, at least going ahead from the present situation, overcoming problems and measures. Bangladesh has recently passed from the list of LDC country with massive economic development. The article should create a guideline for the future policy makers of both government and other sectors to review the alarming situation of chemical induced food contaminants in Bangladesh.

Keywords: Carcinogen; Chemical Intoxication; Food Poisoning; Health Hazard; Pathogen; Adulterants

Abbreviations: BDL-Below Detection Limit; BSTI-Bangladesh Standards and Testing Institution; BCSIRBangladesh Council of Scientific and Industrial Research; ICDDR, B-International Centre for Diarrheal Disease Research, Bangladesh; ETP-Effluent Treatment Plants; IPH-Institute of Public Health; DDT-Dichloro-DiphenylTrichloroethane; BFSA-The Bangladesh Food Safety Authority; BARC-Bangladesh Agricultural Research Council

\section{Introduction}

Contamination is the presence of an unwanted substance where it should not be or at concentrations above recommended. Pollution is contamination that causes adverse biological effects to resident communities. Food contaminants and adulterants gave a new dimension in city life, together rest of the country. Rural people are less exposed to adulteration than urban people because of busy life, arrangement of food/spice item are mostly obtained 
from nearby grocery stores, chain shops and nearby open markets. Recent media reports on the misdeed in the food sector has revealed alarming scenario leading to massive public outcry. Although there is no official statistics regarding food borne illness, it is realized to be a major problem in urban areas of Bangladesh. Contaminated food, filthy and grimy environment of urban cities result in health hazard which may even cause deaths. The healthcare providers/policy makers' role in environmental health is related primarily to being alert to the conditions prevailing in the community and of working with others to adequately control any of the attendant hazards.

\section{Gross Outcomes of Chemical Contamination}

Food remains a significant vehicle of disease organisms. Foodborne disease, more commonly but often incorrectly called "food poisoning," is grossly underreported. In most instances the illness produced by contaminated food is mild and of short duration, but more severe outbreaks (such as hepatitis A, most commonly seen in public restaurants) can occur. Epidemics of food-borne disease are dramatic and sudden, and most people become sick within 6 to 24 hours after consuming the contaminated foodstuffs. The epidemic pattern of food-borne disease presents differently from the gastrointestinal symptoms (e.g. nausea, vomiting, and diarrhea) induced by intestinal enteroviruses. The safety laws and regulations of Bangladesh are as given in Table 1. WHO published-chemical exposure to toxic level is suspected to be involved in causing-

o Carcinoma

o Cardiovascular disease

o Kidney, liver dysfunction Hormonal Imbalance

o Premature birth

o Suppression of Immune system

o Impaired development of nervous system

o Mental health problems and

o Learning disabilities/Cognitive dysfunction

\begin{tabular}{|l|}
\hline Agricultural Products Market Act, 1950 (revised in 1985) \\
\hline Fish Protection and Conservation Act, 1950 (latest amendment in 1995) \\
\hline The Food Grain Supply (Prevention of Prejudicial Activity) Ordinance, 1956 \\
\hline The Bangladesh Pure Food Ordinance, 1959 (Bangladesh Ordinance No. LXVIII of 1959) \\
\hline Agricultural Pest Ordinance 1962 \\
\hline Agricultural Produce Markets Regulation Act, 1964 (revised in 1985) \\
\hline The Cantonments Pure Food Act 1966 \\
\hline Destructive Insects and Pests Rules, 1966 (Plant Quarantine) amended up to 1989 \\
\hline The Bangladesh Pure Food Rules 1967 \\
\hline The Special Powers Act, 1974 \\
\hline The Animals Slaughter (Restriction) and Meat Control (Amendment) Ordinance, 1983 \\
\hline Marine Fisheries Ordinance, 1983 and Marine Fisheries Rules, 1983 \\
\hline Fish and Fish Products (Inspection and Quality Control) Ordinance, 1983 \\
\hline
\end{tabular}




\begin{tabular}{|l|}
\hline The Pesticide Ordinance, 1971 and The Pesticide Rules, 1985 \\
\hline Bangladesh Standards and Testing Institution Ordinance, 1985 (XXXVII of 1985) \\
\hline The Radiation Protection Act, 1987 \\
\hline The Iodine Deficiency Disorder Prevention Act, 1989 \\
\hline The Essential Commodity Act, 1990 \\
\hline National Food Policy 1996 \\
\hline National Agriculture Policy 1996 \\
\hline Fish and Fish Products (Inspection and Quality Control) Rules, 1997 \\
\hline National Food and Nutrition Policy 1997 \\
\hline National Fisheries Policy 1998 \\
\hline National Policy for Safe Water and Sanitation 1998 \\
\hline National Health Policy 2000 \\
\hline Bangladesh Standards and Testing Institution (Amendment) Act, 2003 \\
\hline The Bangladesh Pure Food (Amendment) Act, 2005 \\
\hline Product Labeling Policy 2006 \\
\hline National Livestock Policy 2007 \\
\hline Fish Feed and Animal Feed Act 2010 \\
\hline Export and Import Policy 2009-2012 \\
\hline The Bangladesh Food Safety Act 2013 \\
\hline BSTI Ordinance and many others \\
\hline
\end{tabular}

Table 1: Food Safety Laws and Regulations and Food Standards in Bangladesh.

\subsection{Laboratories for food analysis}

- Public Health Laboratory (IPH)

- $\quad$ BSTI (Ministry of Industries)

- Food testing Laboratory (Ministry of Food and Disaster management)

- Food testing Laboratory (Dhaka City Corporation)

- Institute of Food Radiation Biology, Bangladesh Atomic Energy Commission

- Institute of Food Science Technology, BCSIR

- Institute of Nutrition and Food Science, University of Dhaka

\section{Results and Discussions}

Food adulteration is the most notorious enemy of mankind. Civilization has its own drawback that even causing destruction of itself. Very few people raised voice on this but crippled by the facts of commercialism. The scope of 
this article is confined to chemical food contaminants and adulterants. A few discussions based on real life experience and recent studies or reports from various journals and news articles are summarized here.

\subsection{Food and supply water contamination}

Food and Supply Water Contamination Dhaka city, among huge amount of solid wastes every day from industrial discharge, fossil fuels, fertilizers, sewage sludge, municipality wastes and they are the major sources of heavy metals exposed to crops, vegetables and other food items from soils, causing serious health hazards to human beings [1-3]. A significant deportation of heavy metals like arsenic, cadmium, chromium, copper, lead, mercury, nickel, zinc, molybdenum and vanadium took place from soils to locally grown vegetables (spinach, tomato and cauliflower) grown in industrially polluted soils of Konabari at Gazipur and Keraniganj in Dhaka [4].

Due to absence of effluent treatment plants (ETP), the factory wastes are unloaded to farmlands, and conclusively contaminate the farm produce. In our country we have allowed things like food contamination and pollution to run riot. Till now, neither health ministry or the ministry of science and technology nor the ministry of industries, has conducted any examination of the pesticide- residue levels or toxic chemicals in the foodstuff being marketed [5]. Apart from these, the slum areas are both populated and are in greatest risk of notorious pathogen found both in food sample and supplied water (Table 2).

\begin{tabular}{|c|c|c|}
\hline Presence of organisms in food/water & Overall $n=56$ & \\
\hline Organisms present in Food & n (\%) & $95 \% \mathrm{CI}$ \\
\hline Yeast and mould (>100 CFU/mg) & $48.0(85.7)$ & $0.74-0.93$ \\
\hline Coliforms (>100 CFU/mg) & $41.0(73.2)$ & $0.59-0.84$ \\
\hline B. cereus $(>100 \mathrm{CFU} / \mathrm{mg})$ & $27.0(48.2)$ & $0.35-0.62$ \\
\hline E. coli (>100 CFU/mg) & $17.0(30.4)$ & $0.19-0.44$ \\
\hline Staphylococcus (>100 CFU/mg) & $8.0(14.3)$ & $0.08-0.27$ \\
\hline V. cholera & $2.0(3.5)$ & $0.01-0.14$ \\
\hline Organisms present in Water & Overall $n=16 n(\%)$ & $95 \% \mathrm{CI}$ \\
\hline Total coliforms & $16.0(100)$ & - \\
\hline Faecal coliforms & $16.0(100)$ & - \\
\hline Total aerobic bacterial count & $16.0(100)$ & - \\
\hline Yeast & $16.0(100)$ & - \\
\hline Mould & $16.0(100)$ & - \\
\hline Staphylococcus & $16.0(100)$ & - \\
\hline E. coli & $10.0(62.5)$ & $0.35-0.86$ \\
\hline Faecal streptococci & $9.0(56.3)$ & $0.29-0.79$ \\
\hline
\end{tabular}




\begin{tabular}{|l|l|l|}
\hline Pseudomonas & $7.0(43.8)$ & $0.21-0.71$ \\
\hline
\end{tabular}

Total coliforms and fecal coliforms count (CFU/g) [6].

Table 2: Detection of Foodborne Pathogens in Food And Household Water Samples Collected at Point of Use From Four Slums Of Dhaka City, Bangladesh, December 2015 To May 2016.

According to Dhaka Water Supply and Sewerage Authority (DWASA), it can currently supply 75\% of water demand, out of which $85 \%$ is from groundwater sources (Deep Tube wells). The presence of toxic metals in Elephant road, Dhaka University, Jatrabari, and Demra area and toxic Pentachloro-Phenol (PCP) and existing pathogenic bacterial load in the WASA supplied drinking water sample from different areas of Dhaka city were found to be unacceptable for human consumption (Table 3).

\begin{tabular}{|l|l|l|l|l|l|l|}
\hline $\begin{array}{l}\text { Sample } \\
\text { No. }\end{array}$ & Sampling Area & $\begin{array}{l}\text { Pb content } \\
(\mathbf{m g} / \mathbf{L})\end{array}$ & $\begin{array}{l}\text { Cd content } \\
(\mathbf{m g} / \mathbf{L})\end{array}$ & $\begin{array}{l}\text { Cr content } \\
(\mathbf{m g} / \mathbf{L})\end{array}$ & $\begin{array}{l}\text { As content } \\
(\boldsymbol{\mu g} / \mathbf{L})\end{array}$ & $\begin{array}{l}\text { Total Bacterial } \\
\text { Count c.f.u./100mL }\end{array}$ \\
\hline 1 & Dhaka University & 0.52 & 0.05 & BDL & 0.78 & $4.0 \times 105$ \\
\hline 2 & Bangshal & BDL & 0.03 & BDL & 0.43 & $2.1 \times 104$ \\
\hline 3 & DMCH & BDL & 0.04 & BDL & 0.25 & $1.0 \times 104$ \\
\hline 4 & Basabo & BDL & BDL & BDL & 5.12 & $4.2 \times 106$ \\
\hline 5 & Komlapur & BDL & BDL & BDL & 0.21 & - \\
\hline 6 & Badda & BDL & 0.04 & BDL & 1.29 & $1.0 \times 105$ \\
\hline 7 & Sobujbagh & BDL & 0.04 & BDL & 0.42 & $5.2 \times 106$ \\
\hline 8 & Shagun Bagichaa & BDL & 0.06 & BDL & BDL & $5.0 \times 103$ \\
\hline 9 & Demra & 0.46 & 0.07 & BDL & 0.44 & - \\
\hline 10 & Jatrabari & 0.51 & 0.07 & BDL & 0.15 & $1.5 \times 104$ \\
\hline 11 & Mohammadpur & BDL & 0.07 & BDL & 0.53 & $5.0 \times 103$ \\
\hline 12 & Panthapath & BDL & 0.07 & BDL & 0.29 & $3.0 \times 104$ \\
\hline 13 & Elephant Road & 0.53 & 0.08 & BDL & 0.10 & $2.5 \times 104$ \\
\hline 14 & Shampur & BDL & 0.08 & BDL & 0.56 & $3.5 \times 104$ \\
\hline
\end{tabular}

Table 3: Lead, Cadmium, Chromium and Arsenic content in first 14 water samples [7].

\subsection{Arsenic issue of drinking water}

Twenty million people in Bangladesh are still drinking water contaminated with arsenic, a potentially deadly toxin discovered in supply two decades ago [8]. The Bangladesh government is failed to take initiatives to naturally occurring arsenic in drinking water across large areas of rural Bangladesh, as reported by Human Rights Watch. Approximately 20 years after initially coming to international attention, an estimated 20 million people in Bangladesh-mostly rural poor-still drink contaminated water over the national standard [9]. Bangladesh's health 
system largely neglects the consequence of arsenic exposure on public health. An estimated 43, 000 people die every year from arsenic-related contagion in Bangladesh, according to another study [10]. The government identifies people with arsenic-related contagion primarily via skin abrasion, although the vast majority of those with arsenicrelated illnesses don't develop them. Those exposed are causative agent of cancer, CVD, and lung disease as a result, but many receive no health care at all [11].

\subsection{Food adulterants}

Important food hazards include microbial contamination, pesticide remainder, misused additives, chemical impurities, including biological toxins and adulteration. Although microbiological contamination and chemical hazards are taken into account, it is realized that food adulteration and fraud should not be overlooked considering their consequence in public health [12]. Food adulteration includes various forms of practices, such as mixing, altering, camouflaging the quality of food by mis-labelling, putting up decomposed or expired food, and adding toxic substances [13]. About the proportion of adulterated food items in the market varied between $70 \%$ to $90 \%$. Around $80 \%$ food items in the market were found adulterated in an incidental survey by public health laboratory of Dhaka City Corporation in 2004 [14, 15]. International Centre for Diarrheal Disease and Research, Bangladesh (ICDDR, B), estimated 150 food items in the country. More than $50 \%$ of the food samples they tested were adulterated reported by the Institute of Public Health (IPH). Textile dyes, which are highly noxious to health, are being openly used as food coloring agent [16]. Clay powder is mixed with the mixture of turmeric powder and cold toxic yellow dye to make it yellow. Water and salt are well mixed with these species to increase the weight. Mangoes, watermelon, litchi, watermelon, pineapple, papaya and bananas are artificially ripened using a carcinogenic chemical called ethylene oxide (Table 4). In bananas, calcium carbide is used that becomes a spray Acetile-gas to generate heat.

\begin{tabular}{|l|l|}
\hline Food category and food item & Adulterant \\
\hline Edible oil & Argemone oil, mineral oil and rancid oil given commonly** \\
\hline $\begin{array}{l}\text { Soybean oil } \\
\text { Mustard oil }\end{array}$ & $\begin{array}{l}\text { Palm oil, chemical*, color*, burnt Mobil† from rail locomotives, burnt oil from } \\
\text { electric transformer Chemicals }\end{array}$ \\
\hline Food grain and grain products \\
\hline $\begin{array}{l}\text { Lentils, mugdal, chola, } \\
\text { mosurdal, dabli, mashkolai, } \\
\text { buter dal (lentil types) }\end{array}$ & $\begin{array}{l}\text { Toxic coloring agents*, imported low-quality inedible lentils mixed with textile } \\
\text { dye* and have fungal growth; less expensive Mashkolai dal powdered with } \\
\text { champa color* and sold as mugdal }\end{array}$ \\
\hline Rice & Urea added to make it whiter \\
\hline $\begin{array}{l}\text { Dhekichata chal (husked } \\
\text { rice), ata (course flour) }\end{array}$ & Red toxic color* mixed with rice and ata to sell as husked rice, red atta \\
\hline Muri (puffed rice) & Urea fertilizer to make it whiter and puffier \\
\hline Wheat, corn & Animal feed packaged as human food \\
\hline Semai (vermicelli) & Dalda made with rotten potato, cow intestine, low-quality palm oil \\
\hline
\end{tabular}




\begin{tabular}{|c|c|}
\hline \multicolumn{2}{|l|}{ Vegetables and tubers } \\
\hline Vegetables & Organophosphorus compounds and other pesticides \\
\hline Tomato & Calcium carbide for artificial ripening \\
\hline Potol (pointed gourd), peas & Textile dye* \\
\hline Eggplant & Pesticide* \\
\hline Green peas & Chemically colored* Dabli \\
\hline Potato & Red toxic color* \\
\hline \multicolumn{2}{|l|}{ Spices } \\
\hline Mixed spices (powder) & Brick dust, saw dust, chaler kura (dust from outer layer of rice) \\
\hline Turmeric powder & Brick dust, buter dal, kheshari dal (lentils), artificial powder, color \\
\hline Chili powder & Powder with color \\
\hline Coriander powder & Chaler kura (dust from outer layer of rice), toxic color* \\
\hline Zeera (cumin) powder & Brick dust, toxic color*, powder \\
\hline Pepper & Papaya seed \\
\hline Salt & No iodine \\
\hline \multicolumn{2}{|l|}{ Bakery products } \\
\hline Caket & $\begin{array}{l}\text { Textile dye, chemicals*, inedible date expired ata/maida, fertilizer urea, } \\
\text { substandard inedible dalda, rotten egg }\end{array}$ \\
\hline Biscuit & $\begin{array}{l}\text { Ammonium bicarbonate, sodium cyclamate, fertilizer urea, toxic coloring agents*, } \\
\text { palm oil, burnt oil, outdated inedible ata/maida }\end{array}$ \\
\hline Bread & Rotten egg, outdated ata/maida \\
\hline Fruit and fruit products & (Lead arsenite, Calcium carbide, Ethephon, Formalin, Injection of dye in general) \\
\hline Mango, banana, pineapple & Calcium carbide for artificial ripening \\
\hline Cherry & Koromcha (Carissa carandas, Christ's thorn) with chemical color \\
\hline Orange and lychee juice & Water, flavor, textile dye*, sweet pumpkin, and color \\
\hline Imported juices & Substandard, date expired with new sticker \\
\hline \multicolumn{2}{|l|}{ Snacks } \\
\hline Noodles & Dhekichata chal, lal atta (coarse wheat flour), red potato \\
\hline Chanachur & Fried in burnt mobil $\uparrow$, no potato, imported powder, and color \\
\hline Peyaju, beguni & Toxic dye* \\
\hline \multicolumn{2}{|l|}{ Chocolate, sugar, and honey } \\
\hline Chocolate & Powder, sugar, color*, chemical \\
\hline Sugar & Soda used instead of sugar in food \\
\hline Honey & Sugar syrup \\
\hline \multicolumn{2}{|l|}{ Others } \\
\hline Pickle & Inedible ingredients \\
\hline
\end{tabular}




\begin{tabular}{|l|l|}
\hline Jorda (smokeless tobacco) & Wood dust, chemical \\
\hline Mineral water and & $\begin{array}{l}\text { Tap-water, arsenic contaminated, contaminated with bacteria, no } \\
\text { mineral }\end{array}$ \\
\hline drinking-water $¥$ & *Chemical nature/composition not mentioned/specified; \\
**Argemone oil leads to Epidemic dropsy, Loss of vision, Heart diseases, Tumor, Mineral oil cause liver damage \\
and carcinogenic; Rancid oil leads destroys vitamin A and E \\
$\begin{array}{l}\dagger \text { Polychlorinated biphenyl (PCB) used as coolant in automobiles and transformers; } \\
\ddagger \text { Prepared in unhygienic condition }\end{array}$ \\
\hline
\end{tabular}

Table 4: Adulterants Used in Different Food Items of Vegetable Origin as Reported in Lay Press Reports [17].

Dalda (hydrogenated vegetable oil/ fat popular in South Asia) used in cooking is an example of a worst case false. "Our stomach temperature is 37 degrees Celsius and the melting point is 54 degrees Celsius Dalda. So, there is no reason that Dalda can be engrossed by the body [18]. Most sweetened condensed deserts sold in the market actually comprises palm oil which is used as an alternative for cow's milk and therefore most sweetened condensed milks out there do not contain milk at all [19]. Fish is considered to be an essential protein for people of all ages. Many fish sellers spray formalin in fish in an assorted manner, it makes the fish or fruits stiff and keeps them looking fresh for longer (Table 5). Undoubtedly human health is now under the domination of formalin, in our country about 400 tons formalin is being imported which are goes to human stomach, creates deadly mistreats on long term exposure (Table 6), even though for laboratory or research purposes 100 tons of Formalin is more than enough, 80\% of the imported formalin is directly related to business purposes. Three-fourths of the marketed vegetables, fruits, and fish contain pesticides and formalin residues. The consumption of such foods might lead to serious diseases [20].

\begin{tabular}{|l|l|}
\hline Reasons & Details \\
\hline $\begin{array}{l}\text { A cheap method to prevent Post } \\
\text { harvest Loss }\end{array}$ & $\begin{array}{l}\text { To prevent this post-harvest loss one of the cheap methods is to use formalin } \\
\text { and other toxic chemical which helps to keep this fish fresh for a long time. }\end{array}$ \\
\hline Lack of technical knowledge & $\begin{array}{l}\text { Lack of proper technical knowledge contributes in use of waste material in fish } \\
\text { culture, improper handling after post-harvest and use of formalin and other } \\
\text { toxic elements. }\end{array}$ \\
\hline $\begin{array}{l}\text { Lack of ice box, unavailability of } \\
\text { ice, high price of ice, lack of cold }\end{array}$ & $\begin{array}{l}\text { Ice/Icebox is expensive. Main problem in the market of Bangladesh is there is } \\
\text { lack of cold storage in the market place. As a result, there is no proper way to } \\
\text { preserve unsold fish. }\end{array}$ \\
\hline Lack of awareness & $\begin{array}{l}\text { Most of the traders do not aware of the danger of using these harmful } \\
\text { chemicals. On the other hand, customers are also not properly aware of this } \\
\text { issue. }\end{array}$ \\
\hline
\end{tabular}




\begin{tabular}{|l|l|}
\hline Lack of government initiative & $\begin{array}{l}\text { Co-ordination between authorities is a major issue, does not appear to be any } \\
\text { cohesive view regarding procedures and penalties for the same offence by } \\
\text { officials from same organization. }\end{array}$ \\
\hline Lack of policy framework & $\begin{array}{l}\text { Food laws and regulations are mostly outdated and fragmented. Even the new } \\
\text { Safe Food Act } 2013 \text { is not free from this as it is basically modeled on the Pure } \\
\text { Food Ordinance of } 1959 .\end{array}$ \\
\hline Inadequate Penalties & $\begin{array}{l}\text { Considering the extent of harmfulness of food adulteration, penalties } \\
\text { mentioned in law is insufficient. For an example, the penalty for food } \\
\text { adulteration is maximum term of six months of imprisonment or up to a } \\
\text { maximum fine of BDT } 1000 \text { which is equivalent to EUR 10.77. Considering } \\
\text { the gravity of the offences this punishment is not hard enough. }\end{array}$ \\
\hline
\end{tabular}

Table 5: Underlying Reasons Behind Adulteration Issue in Fish Supply Chain of Bangladesh [21].

Ironically even food color is being adulterated. Cheap food color is finding its way into many types of food. This includes the jilapi, beguni, alu'r chop, piaju. Ice cream, chewing gum, candy, chips, and even biryani may contain huge amounts of low-quality food color. Cooking oil that is so widespread too deep fry items should only be used once but many food vendors and eateries recycle burnt oil. Once the oil is used for cooking, it becomes oxidized. The more the oil is used, more pre-oxide will be created which is really disastrous for the body. It's getting more toxic with continued usage. In 2017, police seized around 3000 eggs suspected to be artificial during a raid in Patiya upazila, Chittagong. They also arrested two men-an egg wholesaler and another is supplier-suspected to be involved in the trade and marketing of fake eggs [22]. Doubt also pointed in rice also. The term 'plastic rice' was focused by the online media around 2010, when China outlined its use for adulteration of a premium rice called Wuchang, which is known for its aroma [23].

\begin{tabular}{|l|l|}
\hline Exposure routes & Effect on human \\
\hline Carcinogenicity & $\begin{array}{l}\text { Formalin has the potential effect to cause cancer, repeated and prolonged exposure } \\
\text { increases the risk of cancers of the lung, nasopharynx, oropharynx and nasal passage }\end{array}$ \\
\hline Reproductive health & It has a harmful effect on reproduction system by inducing oxidative stress. \\
\hline Skin (dermal) & $\begin{array}{l}\text { Prolonged and repeated contact with formalin could cause numbness (lack of feeling) and } \\
\text { a hardening or tanning of the skin }\end{array}$ \\
\hline Eye contact & $\begin{array}{l}\text { Formalin solution splashed in the eye can cause injuries from transient discomfort to } \\
\text { severe such as loss of vision }\end{array}$ \\
\hline
\end{tabular}

Table 6: Effect of Formalin Treated Food Consumption on Health [21]. 
The Institute of Public Health (IPH) in Dhaka and the World Health Organization (WHO) in their joint study on food adulteration in 1994 tested 52 street vendors and found that all of their food samples were contaminated with different types of pathogenic microorganisms. They also conducted another study in 2003 in Dhaka city and found that around $100 \%$ of sweetmeats, $25 \%$ of biscuits, more than $50 \%$ of breads and $60 \%$ of ice creams (Table 7) were extensively adulterated [24].

\begin{tabular}{|c|c|}
\hline \multicolumn{2}{|l|}{ Food category and food item } \\
\hline Hen egg** & $\begin{array}{l}\text { White eggs of farm hens colored red with textile dye* to sell as local hen eggs. } \\
\text { Tortoise eggs sold as hen eggs }\end{array}$ \\
\hline Fish & $\begin{array}{l}\text { Inject formalin through the gills or dip fishes in water treated with chemicals, such } \\
\text { as chloro-fluoro carbon (CFC); DDT† powder to prevent rotting; add red color* to } \\
\text { give fresh look; sell rotten fish }\end{array}$ \\
\hline Dry fish & DDT $\dagger$ \\
\hline Mutton & Buffalo, sheep and beef meat sold as mutton \\
\hline Beef & Buffalo meat sold as beef \\
\hline Halim & Left over bones, intestine \\
\hline \multicolumn{2}{|c|}{ Sweetmeats and dairy products } \\
\hline Butter & Cow's intestine, dalda mixed with color*, powder* \\
\hline $\begin{array}{l}\text { Ghee, dalda (hydrogenated } \\
\text { vegetable oil) } \ddagger\end{array}$ & Banaspati, toxic chemical*, potato smash, cow's fat, intestine \\
\hline Sweetened curd $\$$ & Textile dye* \\
\hline Sweetmeats & $\begin{array}{l}\text { Textile dye named 'thousand power color' and toxic chemicals*; rotten eggs; dalda } \\
\text { made with cow's intestine, saccharin, soybean oil and vegetable oil instead of milk } \\
\text { fat; paste of ground rice and sulphuric acid mixed with milk to make posset }\end{array}$ \\
\hline Jilapi (coil-like juicy sweet) & Fried with Mobil| \\
\hline Halua & Rotten carrot and lau (bottle gourd), chemical* \\
\hline Ice-cream $t$ & $\begin{array}{l}\text { Unsold foul-smelling ice-cream refined and re-packaged, almost no milk, } \\
\text { palm oil for soap manufacturing, textile dye*, low-quality milk powder, } \\
\text { sodium cyclamate }\end{array}$ \\
\hline Imported milk powder & Adulterated, low-quality, date expired, without BSTI approval \\
\hline \multicolumn{2}{|c|}{ Fast food and restaurant food $\dagger$} \\
\hline Jelly, sauce & Toxic coloring agents*, chemicals*, spirit \\
\hline Chicken** & Dead chicken; cooked and raw meat refrigerated together \\
\hline Shrimp & Sold rotten \\
\hline Fish & Fried and raw fish refrigerated together \\
\hline
\end{tabular}


** BLRI also showed that broiler meat and egg showed presence of antibiotic residue of Ciprofloxacin, Sulfonamide, Oxytetracycline and Enrofloxacin in high level.

$\dagger$ Dichloro-diphenyl trichloroethane;

†Prepared in unhygienic condition;

IIPolychlorinated biphenyl (PCB) used as coolant in automobiles and transformers

Table 7: Adulterants Used in Different Food Items of Animal Origin as Reported in Lay Press Reports [17].

Consumption of adulterated food items may cause asthma, sore throat, larynx constriction, bronchitis, skin infections, allergic reactions, diarrhea, hematuria, circulatory failure, numbness, dizziness, kidney failure, stomach cancer, liver cancer, nervous disorders and many other diseases (Table 8). After consumption of adulterated food items, thousands of people are becoming sick. Children are the worst victims. An estimated three million people suffered from diarrhea during 2005-2009 and about 15\% of children died in 2011 as reported by the Directorate General of Health Services [25]. The long-term effects are also very severe especially the incidence of renal failure, liver damage and cancer which are alarmingly increase in Bangladesh. The accumulation of heavy metals, such as lead, chromium and arsenic accumulate in the body may causes kidney and liver failure and develop anomaly among children. Non-selective and aberrant use of antibiotics in poultry without following withdrawal period may result in unexpected residues in animal food and could cause serious health hazards to consumers. Research reports on antibiotic slags in broiler meat and liver from different farms and local markets for the presence of slags of ciprofloxacin, enrofloxacin, oxytetracycline, doxycycline and amoxicilin antibiotics revealed significant level of exposure of antibiotic residues. There's a greater chance of declining immunological responses and can detrimentally affect intestinal microbiota in susceptible individual. According to Prof. Muniruddin Ahmed (Clinical Pharmacy and Pharmacology, Dhaka University) Cooking cannot destroy antibiotic residues, which made them resistant to antibiotic treatment [26]. Most Edible Oil are adulterated and most of the soybean oils, mustard oil and ghee sold to consumers are substandard.

\begin{tabular}{|l|l|l|}
\hline Contaminants & Food/Additives & Possible Outcome \\
\hline $\begin{array}{l}\text { Coloring agents chrome, tartzine } \\
\text { and erythrosine }\end{array}$ & $\begin{array}{l}\text { Spices, sauces, juices, } \\
\text { lentils and oils }\end{array}$ & Cancer in kidney, liver, skin, prostate and lungs \\
\hline Rye flour (ibid) & $\begin{array}{l}\text { Barley, bread and wheat } \\
\text { flour }\end{array}$ & Convulsion and miscarriage \\
\hline Hormone (ibid) & Cauliflower & Infertility of women \\
\hline Coal tar and industrial Dyes & Sweets, Sauce, Pastry \\
cream, powders spices & Carcinogenic \\
\hline Burnt oil & Crispy snack & Food poisoning, reflux, heartburn \\
\hline Agenomato or & $\begin{array}{l}\text { Chinese restaurant food } \\
\text { monosodium glutamate (ibid) }\end{array}$ & Nervous system disorder and depression \\
\hline
\end{tabular}




\begin{tabular}{|c|c|c|}
\hline Flour & Chalk Powder & GI problems \\
\hline Soap & Ghee/Butter & GI problems \\
\hline Calcium Carbide/Ethylene dioxide & Ripening of fruits & Cancer in kidney, liver, skin prostate and lung \\
\hline Urea (ibid) & $\begin{array}{l}\text { For whiten rice and } \\
\text { puffed rice }\end{array}$ & $\begin{array}{l}\text { Damage of kidney and nervous system, Respiratory } \\
\text { problem }\end{array}$ \\
\hline Brick Dust & Chili powder & Respiratory problem \\
\hline Sulfuric acid and palm oil & Condensed milk & Cardiac function problem \\
\hline $\begin{array}{l}\text { Saw dust, Used and exhausted tea } \\
\text { leaves }\end{array}$ & Loose Tea & Respiratory problem \\
\hline Sodium cyclamate & Sweetmeat & Cancer, Fetal abnormality \\
\hline Metanil Yellow Aniline dyes & Turmeric powder & Carcinogenic \\
\hline Melamine & Milk Products & Kidney malfunction \\
\hline Oleomargarine or lard & Butter & Asthma and weakened kidney function \\
\hline $\begin{array}{l}\text { Yellow and Sudan Red colors } \\
\text { (ibid) }\end{array}$ & Chili powder & Tumors in liver and bladder and finally for cancer \\
\hline DDT & Dried fish (Shutki) & $\begin{array}{l}\text { Cancer especially breast cancer, liver cancer and } \\
\text { pancreatic cancer, reproductive damage (Weaken } \\
\text { semen, early menopause, exposure of teratogen and } \\
\text { birth defects) and some neurological damage } \\
\text { reported. }\end{array}$ \\
\hline Bottle and Jar water & Bottle and Jar water & Bottle and Jar water \\
\hline Formalin & $\begin{array}{l}\text { Preservation of fish, } \\
\text { meat, fruit and milk }\end{array}$ & $\begin{array}{l}\text { Throat cancer, blood cancer, childhood asthma and } \\
\text { skin-diseases. }\end{array}$ \\
\hline $\begin{array}{l}\text { Poisonous coloring agents like } \\
\text { auramine, rhodamine b, malachite } \\
\text { green, yellow G, Allura red, and } \\
\text { Sudan red }\end{array}$ & $\begin{array}{l}\text { Applied on food } \\
\text { items for coloring, } \\
\text { brightness and freshness }\end{array}$ & $\begin{array}{l}\text { Damage liver and kidney and cause stomach } \\
\text { cancer, asthma and bladder cancer }\end{array}$ \\
\hline
\end{tabular}

Table 8: Toxic Elements in Noxious Addition of Food/Additives with Possible Outcomes [14, 15, 17, 27-37].

Milk in rural areas is usually devalued with dirty water, which may cause hepatitis. People have now come to know about a newer milk adulteration technique where sorbitol, and detergent used as thickening. ICDDR, B recent studies shows nearly $75 \%$ samples from primary-level producers were contaminated with coliform and more than $50 \%$ with fecal coliform bacteria. At the collection points, samples were found contaminated with a high number of 
coliform bacteria and fecal contamination of more than $90 \%$ while more or less $40 \%$ of the samples had a high E coli count [33]. Vegetable and fruit samples collected from surrounding Dhaka (Savar, Dhamrai and Tongi) show the presence of textile dyes may cause diarrhea, food poisoning and other GI problems in the short-term, but in the long-term toxic materials will accumulate in the body with serious health implications [38].

\subsection{Energy drinks vs carbonated drinks}

The government has decided to prohibit the production, marketing and import of energy drinks under the guise of carbonated beverages with immediate effect [39]. The Bangladesh Standard and Testing Institution (BSTI) at a council meeting on also resolved to take legal action against the companies that have been advertising their products as energy drinks after having them listed as carbonated beverages with BSTI. The move came after the Bangladesh Food Safety Authority (BFSA) wrote to BSTI about the production of energy drinks in the name of carbonated beverages should be discontinued, as the ingredients of the two are significantly different. There is no standard fixed for energy drinks in the country, Industries Minister told parliament once. Authority received complaints about the use of various highly addictive substances, including caffeine and opium, in energy drinks [40]. In 2012, a test conducted by Department of Narcotics Control on energy drinks from several local and foreign merchants had found unrestrained amount of beer, alcohol, artificial caffeine and sildenafil citrate (Generic of Viagra) as ingredients [41]. The production and marketing of energy drinks under a license for carbonated beverage is deception, illegal under several laws including the BSTI Act and the Food Safety Act. Initially, the government will forbid companies to discontinue their production and marketing of energy drinks. Punitive actions will follow if they do not comply, said the official. The government will also revise the import policy in order to boycott the foreign energy drinks with harmful ingredients [42].

\subsection{Safety issues of bottled water}

So-called mineral water supplied to household and offices in jars are not tested at all. Mostly, the water is filled in the jars right away from the tap and sometimes in the empty bottles of some of the well-known mineral bottle brands [43]. The Bangladesh Agricultural Research Council (BARC) has of late made a sensational revelation regarding the quality of water different companies supply for drinking in and around Dhaka. According to the findings of the government study, 'coliform bacteria' (pathogens from feces of humans and animals) has been found in $97 \%$ of socalled filtered water supplied in jars to households, shops and offices in the capital city of Bangladesh. A team of BARC researchers determined the 'horrifying' data while studying the level of minerals in jars and bottled water marketed in Dhaka city. The researchers sampled 250 jars from across the city's familiar places Gabtoli, Mirpur, Mohakhali, Mohammadpur, Dhanmondi, Airport, Uttara, Banani, Gulshan, Rampura, Malibagh, Bshabo, Motijheel, Jatrabari, Keraniganj, Sadarghat, Chaawk Bazar, New market, Elephant Road, Karwan Bazar, Farmgate and on the city's outskirts at Aminbazar, Savar and Ashulia. The level of 'coliform bacteria' in the samples collected from Gulshan, Banani, Bashabo, Chaw Bazar, Elephant Road areas areas was found significantly high in the research [20, 44]. Meanwhile, a mobile court busted six fake mineral water plants in Bosila area, near Dhaka's Mohammadpur 
and convicted six staffers to different terms of jail. The team also seized 2000 jars of water and destroyed those later [45].

\subsection{Food adulteration during Ramadan}

The crime of those selling adulterated and unhygienic food items is very serious and strict action needs to be taken as per law against such guilty persons. According to media reports some 600 field-level sanitary inspectors are working across the country to ensure food safety for all during the holy month of Ramadan. Even more unfortunate is the fact that this nefarious practice increases exponentially during the month of Ramadan. It was found that coloring agents are used in oils, lentils, juices, sauses, spices. Formalin and carbide used in milk, meat, fish and fruit [46]. The shopkeepers and the merchants many of them with a pious fade try to earn a large amount of profit by this unethical practice, and so they play with the life and health of the people. They mix dangerous things in the daily eatables. These merchants and traders are the enemy not only of the nation and their own children but of the entire mankind. The holy Prophet (PBUH) has disowned those who indulge in this immoral business. He said the adulterator is not one of us [47].

\subsection{Sub-standard vermicelli (shemai) and cow fattening ahead of Eid}

Adulterated vermicelli flooded different markets in the capital ahead of Eid-ul-Fitr, one of the biggest religious festivals of the Muslims, posing a serious threat to public health. A section of corrupt businessmen is busy in manufacturing low-grade vermicelli in the port city ahead of Eid-ul-Fitr as the food item has a high demand in the day. According to local sources, some of the factories are using unprocessed palm oil and animal fat to produce Laccha vermicelli while harmful chemicals and toxic color were also used to make the food items. Bangla vermicelli is produced using flour and water and Laccha is produced with sugar, flour, water and oil. Mostly, the vermicelli is dried in unhealthy condition in the rooftop of the factories [48]. An anonymous, a seasonal vermicelli maker said a section of merchant in the city bought the inferior vermicelli and sell them tagging labels of famous companies. BSTI officials left a comment as Bangla vermicelli is used to make by seasonal factory for a certain time, it is not compulsory to take license from BSTI, but the factory should take certificate issued by the Sanitary Inspector [4952]. With Eid-ul-Azha in front, the Poribesh Bachao Andolon (Poba) has recently urged the government to monitor how cattle is being reared and fattened in the farms in the country [53]. Consciously causing such harm to public health so as to raise the price of cows is a crime, and must be dealt with swiftly. The use of steroids, antibiotics, growth hormone and other chemicals is forbidden by the Animal Feed Act 2010. Perpetrators may be faced with a year in prison, a Tk 50, 000 fine, or both. A large number of farmers are engaged in cow fattening just before 3 or 4 months of Eid-Ul-Azha (Muslim festival), when they sell the animals with lucrative price. Visiting different villages in Ataikula, Santhia, Bera upazilas of Pabna, and Baghabari, Shahjadpur areas in Sirajganj, these journalists found that almost every domiciliary was using steroids, antibiotics and other chemicals for months in overt violation of law. Everyone from cattle farm owners to landless farmers wanted to take full advantage of this. These cattlefattening drugs are also widely used in Manikganj, Faridpur, Barisal, Nilphamari, Chuadanga and some other districts. Meat consumption from these animals poses severe health risks for humans, stated by the proficient [54]. 
The changes to the cattle to be slaughtered caused by these injections are not merely cosmetic-severe health damage is done to humans by the consumption of this meat. While most traders would still claim that the fattening chemicals were not harmful, there is reason to believe these chemicals may cause cancer, kidney disease, and infertility in women [55].

\subsection{Penalty imposed on famous eateries}

Isn't it surprising that like many occasional drives against various crimes, the fight against unhealthy food, too, has assumed the character of an occasional activity? While this should have been a continuous and uninterrupted activity round the year across the country, scattered and infrequent moves here and there, leave no everlasting impingement on the sellers and producers of unauthentic food items of all varieties. Gazette reports say that the drive against food adulteration is a recent disport. The Bangladesh Food Safety Authority (BFSA), the state watchdog to regulate the sector is reportedly checking the capital's food markets under the supervision of an executive magistrate. One has reasons to question the logic behind the drive in the capital alone, that too with just one magistrate. The effectiveness of the drive is bound to cause nothing more than a ripple with mobile courts penalizing a few sweetmeat shops, restaurants and if at all, some kitchen market sellers. The fact that such drives, scattered and impassive, failed to bring any control in the country's food market cannot be disputed. However, famous eateries/food chains are not devoid of these cases of adulteration and substandard food staffs. Penalty imposed on these popular food chain/shops should impart an idea to general people that paying high price is not always an indicator of good quality. Even a few of them were condemn more than once or twice for the same reason but below standard food serves never ended (Table 9). For a better view references regards are attached in this table with date published.

\begin{tabular}{|l|l|l|l|}
\hline Eateries/Super Shops & Possible Reasons/Issues & Reference & Date Published \\
\hline Khushbu Biriyani, Gulshan & $\begin{array}{l}\text { Textile dyes for coloring } \\
\text { Biriyani. }\end{array}$ & $\begin{array}{l}\text { Daily Sun and } \\
\text { Daily } \\
\text { Bangladesh }\end{array}$ & $\begin{array}{l}29.05 .18 \text { and } \\
28.05 .18\end{array}$ \\
\hline 'Kosturi Restaurant, Gulshan & $\begin{array}{l}\text { unhygienic environment inside } \\
\text { the restaurant. }\end{array}$ & UNB News & 28.05 .18 \\
\hline $\begin{array}{l}\text { Swapno's Banani } \\
\text { United Catering, Dynamic Food Court, } \\
\text { Dhanmondi }\end{array}$ & Date-expired food. & Daily Sun & 29.05 .18 \\
\hline $\begin{array}{l}\text { Meenabazar's Shantinagar } \\
\text { Rotten and unhealthy foods. }\end{array}$ & Daily Sun & 29.05 .18 \\
\hline Agora and Nandan Super shop & $\begin{array}{l}\text { Soda water without the BSTI } \\
\text { approval and other issues. }\end{array}$ & Daily Sun & 29.05 .18 \\
\hline & $\begin{array}{l}\text { Selling different local and } \\
\text { foreign products having no BSTI }\end{array}$ & Daily Sun & 29.05 .18 \\
\hline
\end{tabular}




\begin{tabular}{|c|c|c|c|}
\hline Boomers Café, Baily Road & $\begin{array}{l}\text { keeping food in unhygienic } \\
\text { environment. }\end{array}$ & Daily Sun & 29.05 .18 \\
\hline SBARRO Cafe & $\begin{array}{l}\text { keeping sauce without a BSTI } \\
\text { approval. }\end{array}$ & Daily Sun & 29.05 .18 \\
\hline Kutumbari Restaurant, Chittagong & $\begin{array}{l}\text { Preserving date-expired fish and } \\
\text { meat. }\end{array}$ & DhakaTribune & 28.06 .16 \\
\hline Bonoful Sweets, Chittagong & $\begin{array}{l}\text { Harmful ammonia for making } \\
\text { biscuits crispy. }\end{array}$ & DhakaTribune & 28.06 .16 \\
\hline Sizzle, Chittagong & $\begin{array}{l}\text { Applying color in making cakes } \\
\text { which is unfit for human } \\
\text { consumption }\end{array}$ & DhakaTribune & 28.06 .16 \\
\hline $\begin{array}{l}\text { Flavor Sweet and Bakers and Fulkoli } \\
\text { Food Products, Chittagong }\end{array}$ & $\begin{array}{l}\text { Date-expired food colour in } \\
\text { manufacturing cake and } \\
\text { sweetmeat. }\end{array}$ & DhakaTribune & 28.06 .16 \\
\hline Fakhruddin Biryani, Baily Road & $\begin{array}{l}\text { Using expired and rotten } \\
\text { ingredients for making Kebab } \\
\text { and Halim. }\end{array}$ & $\begin{array}{l}\text { The News } \\
\text { Today }\end{array}$ & 06.02 .18 \\
\hline 'Mr Bakers, Turag Area & $\begin{array}{l}\text { Preserving date-expired and stale } \\
\text { cake and making biscuits and } \\
\text { toasts without BSTI license. }\end{array}$ & The Daily Sun & 16.06 .17 \\
\hline Arabians Sweets and Bakery & $\begin{array}{l}\text { For not writing manufacturing } \\
\text { and expiry dates on their } \\
\text { packets. }\end{array}$ & The Daily Sun & 16.06 .17 \\
\hline 'Pusty Dairy and Bakery, Malibagh & $\begin{array}{l}\text { For not taking BSTI license for } \\
\text { producing curd. }\end{array}$ & The Daily Sun & 16.06 .17 \\
\hline $\begin{array}{l}\text { 'Lucky Vermicelli Factory' at Matuail in } \\
\text { Jatrabari }\end{array}$ & $\begin{array}{l}\text { Making vermicelli in an } \\
\text { unhygienic environment. }\end{array}$ & The Daily Sun & 16.06 .17 \\
\hline $\begin{array}{l}\text { Yammi Yammi' and 'Ujjal Food } \\
\text { Products' at Pallabi, Mirpur }\end{array}$ & $\begin{array}{l}\text { Making food items in an } \\
\text { unhygienic manner. }\end{array}$ & The Daily Sun & 16.06 .17 \\
\hline $\begin{array}{l}\text { New Food Hotel and Restaurant, Shibganj } \\
\text { Sweets, Tuhin Food Hotel, New Bidyut } \\
\text { Hotel, Tripti Hotel and Cafe RAJ Hotel, } \\
\text { Memory Biriani House, Amir Ali Fish } \\
\text { Shop in Rajshahi City }\end{array}$ & $\begin{array}{l}\text { Selling stale and adulterated } \\
\text { foods. }\end{array}$ & The Daily Star & 17.09 .18 \\
\hline $\begin{array}{l}\text { Maloncho Restaurant at the New Elephant } \\
\text { Road }\end{array}$ & Poor Hygiene. & DhakaTribune & 25.07 .15 \\
\hline Food Corner, Kings Fast Food, Penji Fast & Selling unhygienic food. & United News of & 20.05 .18 \\
\hline
\end{tabular}




\begin{tabular}{|c|c|c|c|}
\hline $\begin{array}{l}\text { Food, Kepray Fast Food, Capital Fast } \\
\text { Food, Al Amin Food, Saikat Fast Food, } \\
\text { Welcome Fast Food and Al Jaber Fast of } \\
\text { Newmarket, Dhaka }\end{array}$ & & $\begin{array}{l}\text { Bangladesh } \\
\text { UNB Beta }\end{array}$ & \\
\hline KFC' and Boomers Baily Road & $\begin{array}{l}\text { Serving expired and chemical- } \\
\text { mixed food items. }\end{array}$ & DhakaTribune & 25.07 .15 \\
\hline Pizza Hut, Baily Road & $\begin{array}{l}\text { Using chemicals in two of its } \\
\text { popular sauces without the } \\
\text { authority's approval. }\end{array}$ & DhakaTribune & 25.07 .15 \\
\hline $\begin{array}{l}\text { Chandrima Restaurant and Mini Chinese, } \\
\text { Kasturi Chhayanir and Thai Chinese } \\
\text { Restaurant and New Star Kebab }\end{array}$ & $\begin{array}{l}\text { Preserving and selling } \\
\text { unhygienic food items. }\end{array}$ & $\begin{array}{l}\text { The } \\
\text { Independent } \\
\text { and Daily } \\
\text { Prothom Alo }\end{array}$ & $\begin{array}{l}19.06 .17 \text { and } \\
18.06 .17\end{array}$ \\
\hline Dawar-E-Mejban, Dhanmondi & $\begin{array}{l}\text { Using harmful chemicals to } \\
\text { color foods. }\end{array}$ & NEWAGE & 25.05 .18 \\
\hline $\begin{array}{l}\text { Ma-Moni Hotel and Restaurant, Suprema } \\
\text { Restaurant, Kosturi Restaurant, Rangpur } \\
\text { City }\end{array}$ & $\begin{array}{l}\text { Preserving foodstuffs in } \\
\text { unhygienic and dirty } \\
\text { environment. }\end{array}$ & $\begin{array}{l}\text { BSS News and } \\
\text { Bangladesh } \\
\text { Post }\end{array}$ & 26.09 .18 \\
\hline $\begin{array}{l}\text { Agora, Shwapno and Meena Bazar } \\
\text { Chittagong }\end{array}$ & For selling rotten meat and fish. & Bdnews24.com & 11.06 .16 \\
\hline Meena Bazar, Agora, Swapna Dhaka & $\begin{array}{l}\text { For selling low-grade packed } \\
\text { products. }\end{array}$ & Bdnews24.com & 09.04 .12 \\
\hline $\begin{array}{l}\text { Agora, Meena Bazar and fast food chain } \\
\text { Coopers, Shantinagar }\end{array}$ & $\begin{array}{l}\text { For keeping expired and stale } \\
\text { food items } \\
\text { (rotten fish, meat and expired } \\
\text { food items). }\end{array}$ & $\begin{array}{l}\text { The Daily Star } \\
\text { and The } \\
\text { Independent }\end{array}$ & $\begin{array}{l}15.05 .16 \text { and } \\
11.05 .16\end{array}$ \\
\hline $\begin{array}{l}\text { Agora in Prabartok, The Grocer, and } \\
\text { Khulshi Mart in Khulshi, Meena Bazar in } \\
\text { Sholoshahar and Shwapno in Gol Pahar } \\
\text { Chittagong }\end{array}$ & $\begin{array}{l}\text { Selling products at hiked up } \\
\text { prices and also selling rotten and } \\
\text { stale items. }\end{array}$ & The Daily Star & 11.06 .16 \\
\hline $\begin{array}{l}\text { Platinum Suites, King's Confectionary, } \\
\text { Kobe Restaurant, Pizza Inn }\end{array}$ & $\begin{array}{l}\text { Selling expired, stale and rotten } \\
\text { foods. }\end{array}$ & Bdnews24.com & 02.06 .18 \\
\hline $\begin{array}{l}\text { Disney Dine Restaurant Kabab Jangson } \\
\text { Limited Nababi Bhoj Solution Lounge, } \\
\text { Shamoli }\end{array}$ & $\begin{array}{l}\text { Selling adulterated food items in } \\
\text { unhygienic conditions. }\end{array}$ & DhakaTribune & 18.05 .18 \\
\hline Mir Al-Amin Hotel and Sharif Hotel & $\begin{array}{l}\text { Producing food items in an } \\
\text { unhygienic condition during }\end{array}$ & Daily Sun & 19.06 .17 \\
\hline
\end{tabular}




\begin{tabular}{|l|l|l|l|}
\hline & Ramadan. & & \\
\hline Alauddin Sweetmeat, Royal Restaurant & Using illegal food colorings, & The Daily Star & 29.05 .12 \\
Lalbagh, Star Hotel and Kabab, Voot & poisonous chemicals and used & & \\
Restaurant, Ambala Sweetmeat, Iftari & cooking oil in Ramadan. & & \\
Bazar and Dominous Pizza in Dhanmondi & & & \\
\hline
\end{tabular}

Table 9: Eateries/Chain Shops Raid List for Adulteration/Substandard Food Serving.

Inadequate monitoring of food markets may have exposed people's health to serious hazards from consumption of substandard and adulterated foods. In the absence of corrective measures, punishing the accused convicts-at times by way of colossal monetary penalties-is not permanent solution of dealing with the complication. A properly organized mechanism with efficient manpower and regular audit round the year can only bring things to some form of order. In this context, it is urgent that the BSFA and allied agencies such as the BSTI and the city corporations which also run such drives maintain a well-coordinated plan of action. It is also important that punitive actions should result in overall quality and standard improvement of food of all varieties. To monitor the situation, inspection and sudden raids are welcome, but it must not be overlooking that inspection is just one of the many ways to rein in food adulteration.

\section{Recommendations}

While contamination of food may be due to disregard, planned adulteration by noxious chmical agents for long shelf-life of products and increasing the volume in size and weight-among the many twisted methods-is so uncontrolled that it is almost impossible to find anyone who does not confront an undesired moment of food-related ailment at least once a year. Consideration of the incidence thus calls for a whole package of initiative actions. In advanced countries this involves a preventive and automated environment of manufacturing, supervision, storing and packaging foods to prevent infection and contamination in the entire chain. However, in situations predominating in this country, it is not merely about maintaining a clean chain but putting in strong preventions so that dirty pool in the business could be gridlocked. Sources of harmful stuffs must be blocked, if necessary, ban on imports or local production. Strong advocacy on the detrimental effects of consumption should be routinely done. At the same time, training on safe and scientific methods of preservation of food products should also be a high priority in an attempt to curb adulteration. Adulteration and contaminant control are a never ending, on the other hand a continuous process. It will increase with time as the civilization go ahead. Community pharmacists and allied health professionals should be familiar of the local occupations, companies, and factories and to be cognizant of the initial outcomes of disease. Again, they should become acquainted with the local community and to acclimate the principles of health and medical care to the particular situations encountered. The pharmacist's continuing education requirements should include watching the local pattern of society and its diseases, and changing the emphasis toward evolving disease patterns and their control. Government and regulatory authorities are to play strong role in controlling food contaminants and adulteration. 


\section{Conclusion}

With constant change to the physical, biological, cultural, social, and economic environment, both healthcare providers and citizens should cultivate an informed awareness of these changes, and health providers should adapt their methods of health education, disease prevention, and disease control to the changes in each community. This is especially true food daily consumed, which require concerted community action for their control, but providers may play a much more fundamental and personal role in controlling food-borne diseases; often, the first indication of an outbreak of food-borne disease is time-limited, with an unusually large number of people seeking relief from health hazards. The crucial role in environmental health is related principally to being alert to the circumstances predominating in the community and of working with others to sufficiently control any of the attendant hazards. Government authorities, NGOs and other private organizations (e.g. Pharmaceutical companies) should take initiatives further to ameliorate food and drinking water situation which is worst among all other previous times. General people should be aware of these facts of mischiefs and take necessary steps on their own. A year-round campaign regarding these issues in public places, electronic media and even in rural areas can bring a change as brought by diarrhea, Vitamin A campaigns back in 70's and 80's.

Compliance with The Ethical Issues: Ethics approval and consent to participate

Animal and Human experiment: N/A

Human Data Submission Approval: N/A

Consent for Publication

Consent to publish Individual Person's data: N/A

\section{Availability of Data and Materials}

Data sharing: Data will be provided on request.

\section{Competing Interests}

The author declares that he has no competing interests

\section{Funding}

Funding from individual/Organization: No fund is received from any individual/organization.

\section{Authors' Contributions}

The individual contributions of authors: N/A

\section{References}

1. Hashem MA, Nur-A-Tomal MS, Abedin MJ, et al. Heavy metal assessment of polluted soil around Hatirjheel Lake of Dhaka city, Bangladesh. Bangladesh J Sci Ind Res 52 (2017): 61-66. 
2. Mahmudul IM. Toxicity of Heavy Metals In Soils And Crops And Its Phyto-Remediation Dissertation For Phd Department Of Soil, Water And Environment university Of Dhaka. Dhaka-1000 (2015).

3. Ashiqur R, Jahan SA, Khairul B, et al. A Comparative Study of Heavy Metal Concentration in Different Layers of Tannery Vicinity Soil and Near Agricultural Soil. American Journal of Analytical Chemistry 7 (2016): 880-888.

4. Rafiqul MI, Jahiruddin M, Alim MA, et al. Consumption of Unsafe Foods: Evidence from Heavy Metal, Mineral and Trace Element Contamination. Department of Soil Science Bangladesh Agricultural University, Mymensingh (2013).

5. Asadullah MK. Bitter Truth Rampant adulteration still a havoc. The Daily Star (2011).

6. Ishita M, Nurun NN, Mustafa M, et al. Children living in the slums of Bangladesh face risks from unsafe food and water and stunted growth is common. Acta Paediatrica 107 (2018): 1230-1239.

7. Murshed S, Ali MH, Mohammad O, et al. Analysis of WASA Supplied Drinking Water Around Dhaka City from Laboratory Analysis Perspective. International Journal of Chemical and Physical Sciences IJCPS 2 (2013): 20-27.

8. Eresh OJ. World Water Day Taking responsibility for our future. The daily Star (2017).

9. Richard P. The politics of arsenic-free water. DhakaTribune (2017).

10. Hasin J. Arsenic in Bangladesh: How to protect 20 million from the world's largest poisoning (2016).

11. Human Rights Watch Nepotism and Neglect. The Failing Response to Arsenic in the Drinking Water of Bangladesh's Rural Poor (2016).

12. FAO/WHO. Assuring food safety and quality: Guidelines for strengthening national food control systems. Rome: Food and Agriculture Organization (2003): 28.

13. Park K. Park's textbook of preventive and social medicine. ( $18^{\text {th }}$ Edn. $)$, Jabalpur: Banarsidas Bhanot (2005): 481.

14. Staff Correspondent. Food adulteration rings alarm bell STAR-RDRS roundtable told most food items adulterated, pose lethal risks to public health. The Daily Star (2011).

15. Mirza FIC. Evaluating Position of Bangladesh to Combat 'Adulterated Food' Crisis in Light of Human Rights. IOSR Journal of Humanities and Social Science (IOSR-JHSS) 19 (2014): 45-54.

16. OP-ED. Public Health Issues in Bangladesh. The Independent (2018).

17. Sharifa N, Tahmeed A. Food Adulteration and Consumer Awareness in Dhaka City, 1995-2011. J Health Popul Nutr 32 (2014): 452-464.

18. Aasha MA, Avik SR, Shamim A, et al. Eating Away Our Health Cover Story. Star Weekend Magazine 4 (2004).

19. Qyshalini N. A doctor reveals that condensed milk contains more sugar than actual milk!. Web Goodtimes (2017).

20. Zubair KH. Time to end food adulteration. The Daily Star (2018).

21. Fatema TZ, Moslah MU. Economic Reasons behind Adulteration Issues in Fish Supply Chain in Bangladesh. Journal of Business Studies 37 (2016). 
22. Ashif SI. Govt: There's no such thing as fake eggs in market. Dhaka Tribune (2017).

23. The New Indian Express. Plastic rice! Are you serious? (2017).

24. Rahman SM, Hoque MA, Talukder MRA. Food security in Bangladesh: utilization, nutrition and food adulteration (paper presented at the National Workshop on Food security, Dhaka, Bangladesh (2005): 4546.

25. Nath DK. Food or poison@bdnews24.com (2014).

26. Emran H. Antibiotics-fed poultry pose threat to public health NEWAGE Bangladesh (2016).

27. Zubair KL, Mohiuddin AK, Bake MA. Food Contaminants: Bangladesh Perspective (2013).

28. Mohammad S. Heavy Metal' in Imported Fish: Samples sent for retest. The Daily Star (2018).

29. Rahman MA, Sultan Z, Rashid MA, et al. Food Adulteration: A Serious Public Health Concern in Bangladesh. Bangladesh Pharmaceutical Journal 18 (2015): 1-7.

30. Nishat TS. Food adulteration: A serious health risk for Bangladesh. risingbd.com (2017).

31. Abu NMAA. Food Safety and Public Health Issues of Bangladesh. European Food and Feed Law Review (2013): 31-40.

32. Nehreen Majed, Md Isreq H Real, Marufa Akter, et al. Food Adulteration and Bio-Magnification of Environmental Contaminants: A Comprehensive Risk Framework for Bangladesh. Front Environ Sci (2016).

33. NewsDesk. Over 75\% pasteurised milk unsafe for direct consumption in Bangladesh: ICDDR, B study. bdnews24.com (2018).

34. Shafkat R. Letters To The Editor Urea in puffed rice. The Daily Star (2013).

35. Rajib KR. Cover Unsafe Food Unhealthy Life. Daily Sun (2015).

36. Editorial. Look for the flies-the future ahead!. Bangladesh J Medicine 25 (2014): 40-41.

37. Mahboob MS. Food Adulteration: The Bangladesh Paradox. Law Journal Bangladesh 2 (2015).

38. Asadullah MK. Slow poisoning continues unabated. The Daily Star (2010).

39. Business. Staff Reporter. Manufactures seek help to dispel doubts about beverages. The Independent (2018).

40. Staff Correspondent. No standard fixed for energy drinks Amu tells JS. The Daily Star (2015).

41. Ashif SI. The dangers lurking in your energy drinks. Dhaka Tribune (2017).

42. Ashif SI. Energy drinks cannot be sold as carbonated drinks. Dhaka Tribune (2017).

43. Joynul M.A. What Are We Drinking: Water or Poison?. Daily Sun (2018).

44. Sarwar MSK. How safe is bottled water for drinking?. The Financial Express (2018).

45. Online Report 6 fake mineral water plants busted in Dhaka, 6 jailed. The Daily Star (2018).

46. Ahamed U. Food adulteration rampant Consumers urge continuous drive against the menace. Daily Sun (2018).

47. Editorial. Food Adulteration. The Independent (2017).

48. Ahamed U. Substandard vermicelli floods city markets. The Daily Sun (2018).

49. Mizanur FMR. Sub-standard vermicelli manufactured ahead of Eid. DhakaTribune (2016). 
50. News Correspondent, Bogra. Substandard vermicelli floods Bogra markets. The Independent (2016).

51. Solaiman S. Adulterated vermicelli floods markets. The Daily Sun (2017).

52. Ahamed U. Food adulteration rampant Consumers urge continuous drive against the menace. Daily Sun (2018).

53. Editorial. Monitor cattle fattening Proper planning can make the difference this time. The daily Star (2018).

54. Pinaki R, Ahmed KT. Cow fattening out of control Traders cut long process short with help of harmful drugs (2015).

55. Tribune Editorial. Put a stop to unethical cow-fattening practices. DhakaTribune 2016. Support The Guardian (2016).

56. Kaferstein FK. Food safety: A commonly underestimated public health issue (1997).

57. Mitali P, Anwara B. Organic Solid Waste Management and the Urban Poor in Dhaka City. Int J Waste Resour 8 (2018): 1.

58. Pollution Abatement Strategies for Rivers and Wetlands in and Around Dhaka City. Parliamentary Standing Committee on Ministry of Environment and Forests (2010).

59. Sadiqur R, Rashad A. Pollution all around A cross-section of people share their opinions with New Age Staff Correspondents. NEWAGE Bangladesh (2018).

60. The Bangladesh Today Improving Dhaka's environment (2018)

61. UN Secretary General 'Water-Related Diseases Responsible For 80 Per Cent Of All Illnesses, Deaths In Developing World', says secretary-general in environment day message Meetings Coverages and Press Release (2003).

Citation: Mohiuddin AK. The Mysterious Domination of Food Contaminants and Adulterants in Bangladesh. Journal of Environmental Science and Public Health 3 (2019): 34-56.

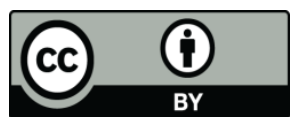

This article is an open access article distributed under the terms and conditions of the

Creative Commons Attribution (CC-BY) license 4.0 